\title{
MEMBANGUN LOYALITAS PELANGGAN MELALUI KEPUASAN YANG DIPENGARUHI OLEH KUALITAS PRODUK, PERSEPSI HARGA DAN CITRA MEREK (Studi Pada Produk Smartphone Merek Oppo)
}

\author{
Putu Sundari Aprelia Dewi ${ }^{(1)}$ \\ Ni Wayan Sri Suprapti ${ }^{(2)}$ \\ ${ }^{(1)(2)}$ Fakultas Ekonomi dan Bisnis Universitas Udayana, Bali, Indonesia \\ email: putusundariad@gmail.com
}

\begin{abstract}
ABSTRAK
Penelitian ini bertujuan untuk menjelaskan pengaruh kepuasan dalam membangun loyalitas pelanggan yang dipengaruhi oleh kualitas produk, citra merek dan persepsi harga. Penelitian dilakukan di Kota Denpasar dengan melibatkan 105 responden. Responden dipilih menggunakan teknik purposive sampling dengan kriteria berjenjang pendidikan minimal SMA/Sederajat, pernah membeli smartphone merek Oppo, dan berdomisili di Kota Denpasar. Instrumen penelitian yang digunakan berupa kuesioner. Kuesioner diuji dengan menggunakan uji validitas dan reliabiltas untuk mengetahui ketepatan dan konsistensi dari kuesioner tersebut. Selanjutnya, data yang terkumpul dari kuesioner dianalisis menggunakan teknik analisis jalur (Path Analysis). Hasil yang ditemukan berupa kualitas produk, persepsi harga dan citra merek memiliki pengaruh positif dan signifikan terhadap kepuasan, kepuasan memiliki pengaruh yang positif dan signifikan terhadap loyalitas pelanggan dan citra merek merupakan variabel yang paling mempengaruhi kepuasan tersebut.
\end{abstract}

Kata kunci: loyalitas pelanggan, kepuasan, kualitas produk, citra merek, persepsi harga

\section{ABSTRACT}

The purpose of this study is to determine the effect of satisfaction in building customer loyalty influenced by the product quality, brand image and price perception. The study was conducted in Denpasar City, involving 105 respondents. Respondents were selected using purposive sampling. The criteria od respondent involved is they have purchased an Opposmartphone. The research instrument used a questionnaire. The data collection is conducted by distributing questionnaires which is tested using the validity test and reliability test to determine the accuracy and consistency of the questionnaire. Furthermore, data collected from the questionnaires are analyzed using path analysis (Path Analysis). The results are found that, product quality, price perception and brand imgae has positive and signifikan impact on customer satisfaction, customer satisfaction has a positive and significant impact on customer loyalty and brand image is the most variable that affect the customer satisfaction

Keywords: brand image, customer loyalty, customer satisfaction, price perception, product quality

\section{PENDAHULUAN}

Smartphone menjadi salah satu perangkat komunikasi yang turut mengalami perkembangan seiring kemajuan teknologi informasi. Smartphone telah berkembang menjadi salah satu produk yang sangat dibutuhkan karena perannya dalam membantu kelancaran aktivitas sehari-hari, hal ini ditandai dengan pesatnya penetrasi produsen smartphone di Indonesia (techno.okezone.com). Berbagai strategi dilakukan oleh perusahaan smartphone agar mampu merebut konsumen di Indonesia, diantaranya dengan menawarkan harga yang terjangkau, kemewahan, dan kualitas produk yang baik. Menyasar segmen pasar yang tepat, menjadi salah satu kunci kesuksesan perusahan smartphone untuk bertahan di industri smartphone Indonesia (Marketeers.com). Data mengenai popularitas smartphone di Indonesia pada fase pertama tahun 2017 seperti disajikan pada Tabel 1. Smartphone merek Samsung memiliki Top Brand Index (TBI) sebesar 46,4\% di Indonesia, angka ini menggambarkan smartphonemerek Samsung merupakan merek dengan tingkat familiaritas tertinggi dibenak konsumen. Terdapat setidaknya 8 perusahaan smartphone yang bersaing memasarkan produknya di Indonesia. Hasil observasi harga smartphone yang dilakukan di Kota Denpasar pada bulan Agustus 2017, diketahui smartphone merek Samsung, Nokia, Blackberry, Smartfren, Lenovo, Oppo dan Asus merupakan produk yang menyasar segmen konsumen kelas menengah.

Aktivitas memotret diri sendiri (selfie) menjadi foto terbanyak yang diupload ke media sosial oleh 
Tabel 1. Top Brand Award Kategori Smartphone Tahun 2017

\begin{tabular}{clcr}
\hline No. & Merek & TBI $(\%)$ & \multicolumn{1}{c}{ Kisaran Harga (Rp) } \\
\cline { 3 - 4 } 1. & Samsung & 46,4 & $1.800 .000-12.000 .000$ \\
2. & Nokia & 8,8 & $800.000-1.200 .000$ \\
3. & Blackberry & 8,0 & $700.000-8.900 .000$ \\
4. & Iphone & 5,1 & $6.000 .000-15.000 .000$ \\
5. & Smartfren & 5,1 & $600.000-2.800 .000$ \\
6. & Lenovo & 4,4 & $2.000 .000-2.300 .000$ \\
7. & Oppo & 4,1 & $1.800 .000-8.000 .000$ \\
8. & Asus & 3,8 & $2.500 .000-4.000 .000$ \\
\hline Sumber:Topbrand-award.com,2017 dan observasi harga pada Agustus 2017 di Kota Denpasar.
\end{tabular}

masyarakat di seluruh dunia. Demam selfie juga terjadi di Indonesia. Pada tahun 2014, Kota Denpasar masuk kedalam 100 kota di dunia yang paling banyak menggungah foto selfie ke media sosial (tekno.kompas.com). Tren ini direspon Oppo dengan menghadirkan smartphone dengan keunggulan kamera selfie. Oppo menawarkan produk dengan harga yang relatif terjangkau, sehingga hal ini dapat menjadi alternatif bagi konsumen yang ingin tetap mengikuti tren, tetapi memiliki daya beli terbatas. Menjual produk dengan harga terjangkau serta menjamin kualitas smartphone yang dijualnya, Oppo yakin dapat menguasai pasar smartphone kelas menengah di Indonesia (marketeers.com).

Selain menyasar segmen pasar yang tepat dan merespon tren yang ada, penting bagi perusahaan untuk menjaga loyalitas pelanggan. Loyalitas pelanggan merupakan komitmen yang dipegang secara mendalam untuk membeli kembali produk atau jasa dimasa mendatang (Kotler dan Keller, 2009 : 138). Produk - produk yang dijual oleh market leader cenderung memiliki konsumen yang lebih loyal jika dibandingkan dengan konsumen produk market follower (Bennett, 2005), namun tidak menutup kemungkinan bagi market follower untuk memiliki konsumen yang loyal terhadap produknya. Menghadirkan produk berkualitas baik dengan harga yang terjangkau dan membangun citra merek yang kuat dapat menjadi salah satu cara perusahaan untuk menciptakan loyalitas konsumen (Chaeriah, 2016).

Kepuasan pelanggan merupakan kunci dalam menciptakan loyalitas pelangan (Espejel et al., 2008). Kepuasan pelanggan adalah perasaan senang atau kecewa yang timbul dari persepsi terhadap kinerja aktual produk (Kotler dan Keller, 2009 : 139). Loyalitas pelanggan akan timbul saat konsumen merasa puas akan produk yang dikonsumsinya (Jayaputra, 2009). Meningkatkan kepuasan pelanggan menjadi tanggungjawab Oppo demi menjaga loyalitas pelanggan. Kepuasan ini diharapkan akan membawa dampak positif lain bagi Oppo, diantaranya saat Oppo mengeluarkan smartphone varian baru, timbul keinginan dibenak pelanggan untuk melakukan pembelian kembali terhadap smartphone merek Oppo.

Menjaga kualitas produk menjadi salah satu cara dalam meningkatkan kepuasan pelanggan. Kualitas produk yang dikonsumsi pelanggan dapat mempengaruhi kepuasan pelanggan (Mulyono dkk., 2007). Kualitas produk adalah totalitas fitur dan karakteristik suatu produk atau layanan untuk memenuhi suatu kebutuhan (Kotler dan Keller, 2009 : 154). Hasil survei APJII (2016) ditemukan bahwa $62 \%$ konsumen mempertimbangan kualitas smartphone yang akan dibelinya. Selain berpengaruh terhadap kepuasan pelanggan, kualitas produk juga memiliki pengaruh yang positif signifikan terhadap loyalitas pelanggan (Wedarini, 2013). Komitmen perusahaan dalam menjaga kualitas smartphone, tidak hanya akan menimbulkan kepuasan pelanggan namun dapat membentuk loyalitas pelanggan. Pelanggan yang loyal akan merekomendasikan smartphone yang digunakannya kepada orang lain.

Selain kualitas produk, persepsi konsumen terhadap harga yang ditawarkan dapat mempengaruhi kepuasan pelanggan. Saat Pelanggan merasa harga yang dibayarkan sesuai dengan kualitas yang didapatkan, maka hal ini akan menimbulkan kepuasan pelanggan (Montung dkk., 2015). Persepsi harga tidak hanya berdampak pada kepuasan pelanggan, tetapi berdampak pula pada loyalitas pelanggan. Kesesuaian harga yang dibayarkan dengan kualitas yang diterima dapat meningkatkan loyalitas pelanggan terhadap suatu produk (Sinaga dan Novianti, 2016).

Persepsi harga berkaitan dengan penilaian terhadap harga yang dipengaruhi oleh persepsi konsumen, sehingga pada akhirnya suatu produk dapat dikataan memiliki harga yang mahal ataupun murah (Peter dan Olson, 2000:228). Menawarkan 
harga bersaing dengan tetap menghadirkan kualitas smartphone yang baik akan menciptakan persepsi harga yang positif dibenak konsumen. Saat konsumen merasa biaya yang dikorbankan sebanding dengan kualitas smartphone yang didapat, maka hal ini tidak hanya akan menciptakan kepuasan pelanggan namun juga menciptakan loyalitas pelanggan.

Meskipun memiliki kualitas produk dan harga yang bersaing, namun Oppo tidak populer dimata konsumen, hal ini terlihat pada data Tabel 1. dimana merek Oppo berada pada posisi ke-7 dalam industri smartphone di Indonesia. Hal ini dapat disebabkan oleh citra merek Oppo yang tidak terlalu kuat. Country of origin (COO) produk dapat mempengaruhi citra merek yang terbentuk dibenak konsumen (Brookshire dan Yoon,2012).

Selama ini produk asal China dianggap sebagai produk yang murah dan mudah rusak, sehingga COO smartphone asal China berperan besar dalam pembentukan citra merek dibenak konsumen. Smartphone asal China memiliki performa yang baik meskipun dengan harga yang tergolong murah, sehingga citra merek yang buruk dibenak konsumen perlahan memudar (Fatih dkk., 2016). Hasil penelitian menemukan bahwa citra merek yang baik akan berpengaruh positif signifikan terhadap kepuasan pelanggan (Kurniawati dkk.,2014). Citra merek yang baik akan berdampak pada positif terhadap loyalitas pelanggan (Taufandra dan Rahanatha, 2014). Usaha perusahaan dalam meningkatkan nilai dari citra mereknya, diharapkan tidak hanya mampu meningkatkan kepuasan pelanggan tetapi juga dapat meningkatkan loyalitas pelanggan terhadap produk smartphone.

Penelitian mengenai pengaruh kualitas produk, harga dan citra merek terhadap loyalitas pelanggan produk smartphonepernah dilakukan oleh Chaeriah (2016). Penelitian tersebut menemukan bahwa, kualitas produk, persepsi harga, dan citra merek memiliki pengaruh positif signifikan terhadap loyalitas pelanggan. Hasil yang berbeda ditemukan dalam penelitian Sembiring dkk. (2014), dalam penelitian tersebut kualitas produk tidak signifikan berpengaruh terhadap loyalitas pelanggan. Penelitian oleh Sulistiyanto dan Soliha (2015) menemukan bahwa persepsi harga tidak memberikan pengaruh pada loyalitas pelanggan. Hasil yang negatif juga ditemukan pada penelitian yang dilakukan oleh Sinaga dan Novianti (2016), dalam penelitain tersebut ditemukan bahwa citra merek tidak berpengaruh signifikan terhadap loyalitas pelanggan.
Sejumlah penelitian yang disajikan menunjukkan adanya hasil yang tidak konsisten dalam hubungan antara kualitas produk, persepsi harga, dan citra merek terhadap loyalitas. Hal ini diduga karena terdapat satu variabel yang berperan penting dalam menentukan loyalitas yaitu kepuasan pelanggan. Sebagaimana dinyatakan oleh Kotler dan Keller (2009:139) bahwa pelanggan yang puas menyebabkan terjadinya loyalitas. Penelitian tentang fenomena produk smartphone merek Oppo ini akan membahas mengenai loyalitas pelanggan yang dibentuk oleh kualitas produk, persepsi harga, dan citra merek melalui kepuasan pelanggan.

Tujuan dari penelitian ini adalah untuk menjelaskan pengaruh kualitas produk, persepsi harga dan citra merek terhadap kepuasan pelanggan produk smartohpne merek Oppodan untuk menjelaskan pengaruh kepuasan terhadap loyalitas pelanggan smartphone merek Oppo. Penelitian ini dapat memberikan 2 kegunaan, yaitu kegunaan teoritis dan kegunaan praktis. Kegunaan teoritis dapat berupa memberikan kontribusi empiris tentang hubungan antara variabel kualitas produk, persepsi harga, citra merek, kepuasan dan loyalitas pelanggan bagi pengembangan ilmu pemasaran. Kegunaan praktis dapat berupa menjadi referensi bagi perusahaan dalam memanfaatkan aspek kualitas produk, persepsi harga, citra merek, kepuasan pelanggan sebagai strategi meningkatkan loyalitas pelanggan terhadap produk smartphone merek Oppo.

Produk adalah segala sesuatu yang dapat ditawarkan ke pasar untuk mendapatkan perhatian, dibeli, digunakan, atau dikonsumsi yang dapat memuaskan keinginan dan kebutuhan (Kotler dan Amstrong, 2010 : 248). Konsep produk menyatakan bahwa konsumen akan lebih menyukai produk produk yang menawarkan fitur yang paling bermutu, berprestasi atau inovatif (Saraswati dan Rahyuda, 2017). Kualitas produk adalah keseluruhan fitur dan karakteristik produk atau layanan yang sesuai dengan kemampuan untuk memuaskan konsumen (Kotler dan Keller, 2009 : 143).

Indikator - indikator yang dapat digunakan dalam mengukur kualitas produk menurut Kotler dan Keller (2009 : 149), diantaranya kinerja, berupa karakteristik mutu produk dalam menjalankan fungsi utamanya dari sudut pandang pengguna. Keistimewaan berupa manfaat tambahan yang dimiliki produk, dan estetika, merupakan tampilan produk.

Harga adalah nilai suatu barang yang dinyatakan dengan uang (Alma, 2005: 169). Perusahaan perlu 
memperhatikan harga karena dalam persaingan usaha, harga yang ditawarkan pesaing bisa lebih rendah dengan menawarkan kualitas yang sama bahkan lebih baik (Ghanitama dan Kamal, 2012). Konsumen pada umunya memiliki kesan barang mewah kepada produk dengan harga mahal, dan berlaku hal yang sebaliknya (Asadi et al., 2014). Kesesuaian harga dan kualitas yang ditawarkan perlu menjadi perhatian demi terciptanya citra yang baik (Beneke dan Zimmerman, 2014). Persepsi konsumen tentang harga yang sesuai dengan kualitas produk yang didapat berpengaruh terhadap kepuasan pelanggan (Iglesias dan Guillen, 2004).

Nugraheni dan Ferdinan (2013) mengemukakan terdapat 4 indikator yang dapat digunakan untuk mengukur persepsi harga, diantaranya: Keterjangkauan harga, berupa harga yang ditawarkan merupakan harga yang sesuai dengan daya beli konsumen, Kesesuaian harga berkaitan dengan perbandingan harga terhadap kualitas yang ditawarkan, daya saing harga yaitu harga yang diberikan produsen merupakan harga yang bersaing dengan produk yang dijual produsen lain pada jenis produk yang sama, dan harga yang ditawarkan sesuai dengan manfaat yang dapat diperoleh konsumen dari produk yang dibelinya.

Citra merek dapat juga diartikan sebagai asosiasi merek yang muncul didalam benak konsumen dalam jangka waktu yang lama dan bersifat konsisten (Koubaa, 2008). Citra merek produk yang baik akan mendorong para calon pembeli untuk membeli produk tersebut dari pada membeli produk yang sama dari merek lain (Seno dan Bryan, 2007).

Indikator - indikator yang dapat digunakan dalam mengukur citra merek produk menurut Shimp (2014 : 41) diantaranya : Favorable berupa kemampuan merek agar mudah diingat konsumen, manfaat simbolis yang berkaitan dengan kebutuhan akan pengakuan sosial dan penghargaan diri, dan kompetensi (Competence), berupa merek yang memiliki nilai tinggi pada dimensi ini dianggap memiliki citra yang andal, cerdas, dan sukses.

Kepuasan pelanggan adalah perasaan senang atau kecewa seseorang yang timbul karena membandingkan kinerja yang dipersepsikan produk atau hasil terhadap ekspektasi merek (Kotler dan Keller, 2009 : 139). Pelanggan yang puas akan memiliki rencana untuk mengulangi pembelian (Consuegra et al., 2007). Kepuasan pelanggan akan berdampak pada loyalitas (Sondoh et al., 2007). Kepuasan pelanggan dapat tercipta saat perusahaan dapat memenuhi kebutuhan pelanggannya dengan baik (Moraga et al., 2008). Konsumen akan merasa telah membuah keputusan yang tepat saat kepuasannya terpenuhi (Sulistiyanto dan Soliha, 2016).

Indikator yang dapat digunakan dalam mengukur kepuasan pelanggan menurut Nurlinda (2013) diantaranya: kepuasan pelanggan keseluruhan dan konfirmasi harapan yang berkaitan dengan ketidaksesuaian antara harapan pelanggan dengan kinerja aktual produk.

Loyalitas merupakan sikap menyenangi terhadap suatu produk yang direpresentasikan dalam pembelian yang konsisten terhadap produk dengan merek yang sama sepanjang waktu (Sutisna, 2001 : 41). Konsumen yang loyal tidak hanya akan mengunakan produk dengan merek yang sama dikemudian hari, namun konsumen yang loyal akan merekomendasikan produk yang pernah dikonsumsinya kepada orang lain (Yu dan Dean, 2000). Dalam menjaga loyalitas pelanggan, usaha yang dapat dilakukan oleh perusahaan diantaranya dengan menjaga hubungan baik dengan pelanggan, maupun memberikan reward kepada pelanggan yang telah setia mengkonsumsi produk mereka (Divet et al., 2003). Penerapan strategi marketing yang tepat tidak hanya menjadi kunci dalam menjaga loyalitas pelanggan, namun dampaknya lebih jauh dapat menjaga loyalitas karyawan (Duffy, 2003). Indikator yang dapat digunakan untuk mengukur Loyalitas pelanggan dapat diukur dengan menggunakan beberapa indikator (Rachmawati,2014) diantaranya pembelian ulang, rekomendasi, dan komitmen.

\section{HIPOTESIS PENELITIAN}

Penelitian oleh Mulyono dkk. (2007), Hermawan (2011), Putri dkk. (2013), Wedarini (2013), dan Bailia dkk. (2014) menemukan bahwa kualitas produk sebagai variabel bebas berpengaruh positif yang signifikan terhadap kepuasan pelanggan sebagai variabel terikat, sehingga semakin tinggi kualitas produk maka semakin tinggi kepuasan pelanggan. Berdasarkan hasil empiris pada penelitian tersebut, hipotesis yang dapat diajukan dalam penelitian ini adalah,

$\mathrm{H}_{1}$ : Kulitas produk berpengaruh positif dan signifikan terhadap kepuasan pelanggan.

Penelitian oleh Yoganthara (2013), Montung dkk. (2015), Liman (2016) Darmawan dan Ekawati (2017), dan Sulastri (2017) menemukah bahwa persepsi harga berpengaruh positif dan signifikan secara parsial terhadap kepuasan pelanggan. Berdasarkan hasil empiris pada penelitian tersebut hipotesis yang dapat diajukan dalam penelitian ini adalah, 
$\mathrm{H}_{2}$ : Persepsi harga berpengaruh positif dan signifikan terhadap kepuasan pelanggan.

Penelitian oleh Silva dan Giraldi (2010), Saputra (2013), Harianto dan Subagio (2013), Kurniawati dkk. (2014), Pusparani dan Rastini (2014) dan Susanti dan Wardana (2015) menemuka bahwa citra merek berpengaruh positif dan signifikan terhadap kepuasan pelanggan. Berdasarkan hasil empiris pada penelitian tersebut, hipotesis yang dapat diajukan dalam penelitian ini adalah

$\mathrm{H}_{3}$ : Citra merek berpengaruh positif dan signifikan terhadap kepuasan pelanggan.
Penelitian oleh Jayaputra (2009), Luthfi (2011), Kurniasari dan Ernawati (2012), Rachmawati (2014) dan Margaretha dan Sunaryo (2014) menemukan bahwa kepuasan berpengaruh positif dan signifikan terhadap loyalitas pelanggan. Berdasarkan hasil empiris pada penelitian di atas, hipotesis yang dapat diajukan dalam penelitian ini adalah

$\mathrm{H}_{4}$ : Kepuasan pelanggan berpengaruh positif dan signifikan terhadap loyalitas pelanggan

Berdasarkan tinjauan pustaka dan empiris, maka disusun sebuah kerangka konseptual.

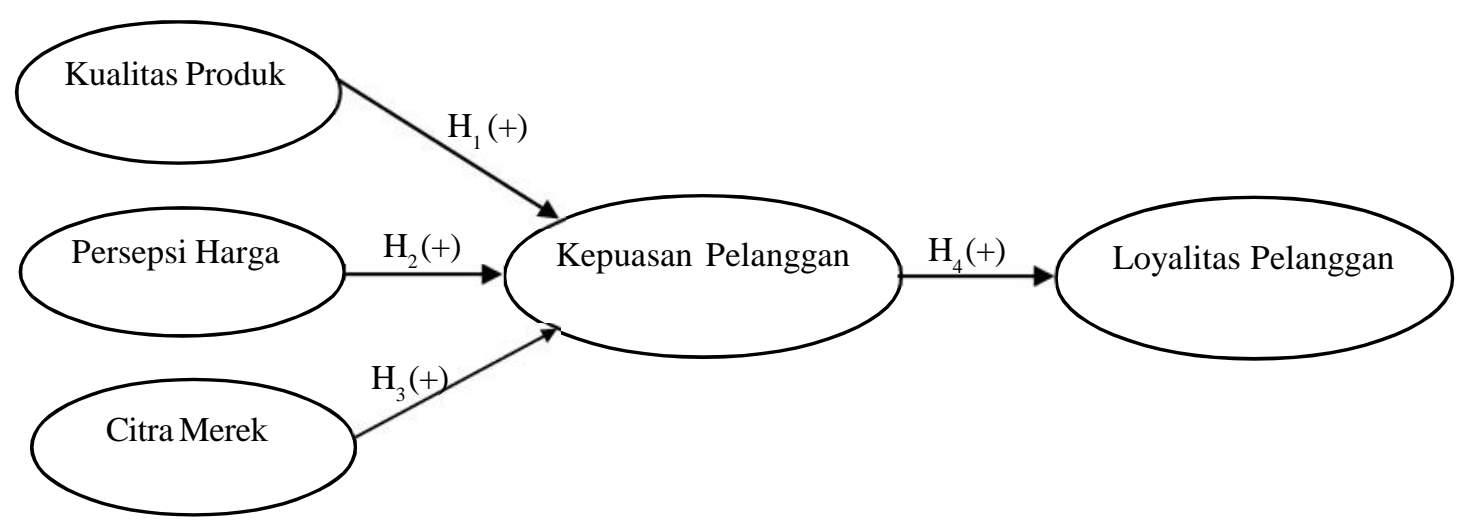

Gambar 1. Kerangka Konseptual

\section{METODE PENELITIAN}

Jenis penelitian ini adalah kuantitatif kausalitas. Penelitian dilakukan di Kota Denpasar. Objek yang digunakan adalah perilaku konsumen, khususnya loyalitas penggunaan smartphone merek Oppo. Penelitian ini menggunakan 3 jenis variabel, yaitu variabel independen berupa kualitas produk persepsi harga dan citra merek. Variabel intervening berupa kepuasan pelanggan. Variabel dependen berupa loyalitas pelanggan. Indikator yang digunakan disajikan dalam Tabel 2.

Tabel 2. Indikator Penelitian

\begin{tabular}{|c|c|c|c|}
\hline Variabel & & Indikator & Sumber \\
\hline Kualitas Produk $\left(\mathrm{X}_{1}\right)$ & $\begin{array}{l}\mathrm{X}_{1.1} \\
\mathrm{X}_{1.2} \\
\mathrm{X}_{1.3}\end{array}$ & $\begin{array}{l}\text { Kinerja } \\
\text { Keistimewaan } \\
\text { Estetika }\end{array}$ & $\begin{array}{l}\text { Kotler dan Keller } \\
\qquad(2009)\end{array}$ \\
\hline Persepsi Harga $\left(\mathrm{X}_{2}\right)$ & $\begin{array}{l}\mathrm{X}_{2.1} \\
\mathrm{X}_{2.2} \\
\mathrm{X}_{2.3} \\
\end{array}$ & $\begin{array}{l}\text { Daya saing harga } \\
\text { Keterjangkauan harga } \\
\text { Kesesuaian manfaat } \\
\end{array}$ & $\begin{array}{l}\text { Nugraheni dan Ferdinan } \\
\text { (2013) }\end{array}$ \\
\hline Citra Merek $\left(\mathrm{X}_{3}\right)$ & $\begin{array}{l}\mathrm{X}_{2.1} \\
\mathrm{X}_{2.2} \\
\mathrm{X}_{2.3}\end{array}$ & $\begin{array}{l}\text { Favorable } \\
\text { Manfaat simbolis } \\
\text { Kompetensi }\end{array}$ & Shimp (2014) \\
\hline Kepuasan Pelanggan (M) & $\begin{array}{l}\mathrm{M}_{1} \\
\mathrm{M}_{2} \\
\mathrm{M}_{3}\end{array}$ & $\begin{array}{l}\text { Kepuasan secara keseluruhan. } \\
\text { Konfirmasi harapan. } \\
\text { Keputusan tepat }\end{array}$ & $\begin{array}{l}\text { Sulistiyanto dan Soliha } \\
\text { (2016), Nurlinda (2013) }\end{array}$ \\
\hline Loyalitas Pelanggan (Y) & $\begin{array}{l}\mathrm{Y}_{1} \\
\mathrm{Y}_{2} \\
\mathrm{Y}_{3}\end{array}$ & $\begin{array}{l}\text { Komitmen } \\
\text { Niat pembelian ulang } \\
\text { Rekomendasi }\end{array}$ & Rachmawati (2014) \\
\hline
\end{tabular}

Jumlah sampel yang digunakan adalah 105 sampel. Sampel ditentukan dengan metode non probality sampling berupa purposive sampling.
Metode ini digunakan karena responden ditentukan berdasar kriteria berupa jenjang pendidikan minimal SMA atau sederajat, responden pernah membeli 
produk smartphone merek Oppo dan berdomisili di Kota Denpasar.

Data yang digunakan terdiri atas data kualiatif dan data kualitatif. Data kualitatif berupa pendapat responden dalam kuesioner, sedangkan data kuantitatif berupa usia dari responden. Sebagian besar data bersumber dari sumber primer yaitu responden. Data dari sumber sekunder berupa publikasi demografi penguna internet oleh Asosiasi Penyelenggara Jasa Internet Indonesia, publikasi tingkat popularitas merek smartphone di Indonesia pada tahun 2017 oleh TOP Brand Award, dan artikel dari situs berita online.

Data dikumpulkan menggunakan instrumen penelitian berupa kuesioner. Kuesioner terdiri atas dua bagian yaitu bagian yang menanyakan identitas responden dan pernyataan terkait indikator variabel penelitian. Tiap indikator variabel penelitian diberi pilihan jawaban secara tertutup dengan menggunakan Skala Likert. Kuesioner diuji validitas dan reliabilitasnya. Data yang diperoleh diolah dengan menggunakan statistik deskriptif dan statistik inferensial. Statistik inferensial berupa analisis jalur.
Statistik deskriptif berupa rata-rata usia responden, dan rata-rata skor jawaban dari kuesioner. Ratarata skor jawaban responden dikelompokkan ke dalam rentang penilaian seperti pada Tabel 3 .

Tabel 3. Kriteria Penlilaian

\begin{tabular}{ccc}
\hline No. & Rentang & Kriteria \\
\hline 1. & $1,00-1,79$ & Sangat Tidak Baik \\
2. & $1,80-2,59$ & Tidak Baik \\
3. & $2,60-3,39$ & Cukup Baik \\
4. & $3,40-4,19$ & Baik \\
5. & $4,20-5,00$ & Sangat Baik \\
\hline
\end{tabular}

Sumber: Wirawan,2002.

Profil responden diklasifikasikan berdasarkan variabel demografi berupa usia, jenis kelamin, usia dan pelekerjaan. Secara rinci profil responden tersebut disajikan dalam Tabel 4.

Data pada Tabel 4. diketahui pada variabel usia, didominasi oleh responden yang berusia pada rentang 17- 21 tahun, secara keseluruhan responden memiliki rata - rata usia 24 tahun. Responden didominasi oleh perempuan sebesar 69,5 persen. Untuk jenjang

Tabel 4. Profil Responden

\begin{tabular}{cclcc}
\hline No. & Variabel & \multicolumn{1}{c}{ Klasifikasi } & $\begin{array}{c}\text { Jumlah } \\
(\text { Orang })\end{array}$ & $\begin{array}{c}\text { Persentase } \\
(\%)\end{array}$ \\
\hline 1. & Usia & $17-21$ tahun & 56 & 53,3 \\
& & $22-26$ tahun & 31 & 29,5 \\
& $27-31$ tahun & 6 & 5,7 \\
& $32-36$ tahun & 2 & 1,9 \\
& & diatas 37 tahun & 10 & 9,5 \\
& & Jumlah & $\mathbf{1 0 5}$ & $\mathbf{1 0 0 , 0}$ \\
2. & Jenis Kelamin & 73 & 69,5 \\
& & Perempuan & 32 & 30,5 \\
& & Laki - Laki & $\mathbf{1 0 5}$ & $\mathbf{1 0 0 , 0}$ \\
3. & Jenjang & SMA / Sederajat & 57 & 54,3 \\
& Pendidikan & Perguruan Tinggi & 48 & 45,7 \\
& & Jumlah & $\mathbf{1 0 5}$ & $\mathbf{1 0 0 , 0}$ \\
4. & Pekerjaan & Mahasiswa & 68 & 64,8 \\
& & Ibu Rumah Tangga & 3 & 2,9 \\
& & Karyawan Swasta & 8 & 7,6 \\
& & PNS & 17 & 16,2 \\
& & Wiraswasta & 9,6 \\
& & Jumlah & $\mathbf{1 0 5}$ & $\mathbf{1 0 0 , 0}$ \\
\hline
\end{tabular}

Sumber: Data diolah, 2017

pendidikan, sebesar 54,3 persen responden berpendidikan minimal SMA/ sederajat. Pada kategori pekerjaan sebesar 64,8 persen responden didominasi oleh mahasiswa.

Kuesioner yang berisi pernyataan dari 105 reponden diuji menggunakan uji validitas dan reliabilitasnya. Hasil dari uji - uji tersebut disajikan dalam Tabel 5.
Data Tabel 5. dapat diketahui bahwa semua indikator memiliki nilai koefisien korelasi $\geq 0,3$ dan nilai alpha cronbach $\geq 0,6$ sehingga indikator dalam kuesioner telah layak dan memiliki konsistensi untuk digunakan. Penilaian responden mengenai masing masing variabel dapat diketahui melalui hasil dari deskripsi masing - masing variabel tersebut, disajikan dalam Tabel 6. 
Tabel 5. Hasil Uji Validitas dan Reliabilitas

\begin{tabular}{|c|c|c|c|c|}
\hline No. & Variabel & Indikator & Koef. Korelasi & Alpha cronbach \\
\hline \multirow[t]{3}{*}{1.} & Kualitas produk & Kinerja & 0,940 & \\
\hline & & Keistimewaan & 0,943 & 0,923 \\
\hline & & Estetika & 0,925 & \\
\hline \multirow[t]{3}{*}{2.} & Persepsi harga & Daya saing harga & 0,910 & \\
\hline & & Keterjangkauan harga & 0,863 & 0,864 \\
\hline & & Kesesuaian manfaat & 0,894 & \\
\hline \multirow[t]{3}{*}{3.} & Citra merek & Favorable & 0,925 & \\
\hline & & Manfaat simbolis & 0,944 & 0,910 \\
\hline & & Kompetensi & 0,893 & \\
\hline \multirow[t]{3}{*}{4.} & Kepuasan & Kepuasan secara keseluruhan & 0,865 & \\
\hline & pelanggan & Konfirmasi harapan & 0,925 & 0,884 \\
\hline & & Keputusan tepat & 0,922 & \\
\hline \multirow{3}{*}{5.} & Loyalitas & Komitmen & 0,922 & \\
\hline & pelanggan & Minat pembelian ulang & 0,934 & 0,917 \\
\hline & & Rekomendasi & 0,932 & \\
\hline
\end{tabular}

Sumber: Data diolah, 2017

Data pada Tabel 6. dapat diketahui bahwa penilaian responden terhadap variabel kualitas produk, persepsi harga, kepuasan pelanggan dan loyalitas pelanggan masuk kedalam kriteria sangat baik. Sementara, penilaian responden terhadap variabel citra merek adalah baik.

Hasil tabulasi data kuesioner selanjutnya diolah menggunakan teknik analisis jalur. Hasil dari analisis

Tabel 6. Penilaian Responden Terhadap Variabel

\begin{tabular}{|c|c|c|c|c|c|c|c|}
\hline \multirow{2}{*}{ Variabel } & \multirow{2}{*}{ Indikator } & \multicolumn{5}{|c|}{ Distribusi Jawaban (\%) ; n = 105} & \multirow{2}{*}{$\begin{array}{c}\text { Rata - } \\
\text { rata skor }\end{array}$} \\
\hline & & 1 & 2 & 3 & 4 & 5 & \\
\hline \multirow{4}{*}{$\begin{array}{l}\text { Kualitas } \\
\text { produk } \\
\left(\mathrm{X}_{1}\right)\end{array}$} & Kinerja $\left(\mathrm{X}_{1.1}\right)$ & 0 & 0 & 12,4 & 49,5 & 38,1 & 4,26 \\
\hline & Keistimewaan $\left(\mathrm{X}_{1.2}\right)$ & 0 & 0 & 8,6 & 41,0 & 50,5 & 4,42 \\
\hline & Estetika $\left(\mathrm{X}_{1.3}\right)$ & 0 & 1,0 & 11,4 & 50,5 & 37,1 & 4,24 \\
\hline & & & & & \multicolumn{2}{|c|}{ Jumlah } & 4,30 \\
\hline \multirow{4}{*}{$\begin{array}{c}\text { Persepsi } \\
\text { harga } \\
\left(\mathrm{X}_{2}\right)\end{array}$} & Daya saing harga $\left(\mathrm{X}_{2.1}\right)$ & 0 & 1,0 & 9,5 & 50,5 & 39,0 & 4,28 \\
\hline & Keterjangkauan harga $\left(\mathrm{X}_{2.2}\right)$ & 0 & 0 & 9,5 & 58,1 & 32,4 & 4,23 \\
\hline & Kesesuaian manfaat $\left(\mathrm{X}_{2.3}\right)$ & 0 & 0 & 9,5 & 53,3 & 37,1 & 4,28 \\
\hline & & & & & \multicolumn{2}{|c|}{ Jumlah } & 4,26 \\
\hline Citra & Favorable $\left(X_{3.1}\right)$ & 0 & 0 & 10,5 & 61,0 & 28,6 & 4,18 \\
\hline merek & Manfaat simbolis $\left(\mathrm{X}_{3.2}\right)$ & 0 & 1,0 & 16,2 & 56,2 & 26,7 & 4,09 \\
\hline \multirow[t]{2}{*}{$\left(\mathrm{X}_{3}\right)$} & Kompetensi $\left(\mathrm{X}_{3.3}\right)$ & 0 & 0 & 5,7 & 61,9 & 32,4 & 4,27 \\
\hline & & & & & \multicolumn{2}{|c|}{ Jumlah } & 4,18 \\
\hline Kepuasan & Kepuasan secara keseluruhan $\left(\mathbf{M}_{1}\right)$ & 0 & 0 & 13,3 & 60,0 & 26,7 & 4,13 \\
\hline pelanggan & Konfirmasi harapan $\left(\mathrm{M}_{2}\right)$ & 0 & 0 & 5,7 & 61,9 & 32,4 & 4,27 \\
\hline \multirow[t]{2}{*}{$(\mathrm{M})$} & Keputusan tepat $\left(\mathrm{M}_{3}\right)$ & 0 & 0 & 13,3 & 51,4 & 35,2 & 4,22 \\
\hline & & & & & \multicolumn{2}{|c|}{ Jumlah } & 4,21 \\
\hline Loyalitas & Komitmen $\left(\mathrm{Y}_{1}\right)$ & 0 & 0 & 10,5 & 59,0 & 30,5 & 4,20 \\
\hline pelangga & Minat pembelian ulang $\left(\mathrm{Y}_{3}\right)$ & 0 & 0 & 13,3 & 46,7 & 40,5 & 4,27 \\
\hline \multirow[t]{2}{*}{$(\mathrm{Y})$} & Rekomendasi $\left(\mathrm{Y}_{3}\right)$ & 0 & 1,0 & 10,5 & 45,7 & 42,9 & 4,30 \\
\hline & & & & & \multicolumn{2}{|c|}{ Jumlah } & 4,26 \\
\hline
\end{tabular}

Sumber: Data diolah, 2017

jalur tersebut disajikan dalam Tabel 7. Data pada Tabel 7, diketahui nilai beta dari masing-masing variabel, sehingga persamaan struktural untuk hipotesis 1, 2 dan 3 dapat disusun sebagai berikut : $\mathrm{M}=0,246 \mathrm{X}_{1}+0,272 \mathrm{X}_{2}+0,337 \mathrm{X}_{3}+\varepsilon_{1}$

Data pada Tabel 8, dapat diketahui nilai beta dari variabel kepuasan, sehingga persamaan struktural untuk hipotesis 4 dapat disusun sebagai berikut : $\mathrm{Y}=0,662 \mathrm{M}+\varepsilon_{2}$
Keterangan :

$\beta_{1}=$ Kualitas Produk

$\beta_{2}=$ Persepsi Harga

$\beta_{3}=$ Citra Merek

$M=$ Kepuasan Pelanggan

$\mathrm{Y}=$ Loyalitas Pelanggan

$\varepsilon_{1}=$ error 1

$\varepsilon_{2}=$ error 2 
Tabel 7. Hasil Analisis Jalur Persamaan Regresi 1

\begin{tabular}{|c|c|c|c|c|c|c|}
\hline \multirow{2}{*}{\multicolumn{2}{|c|}{ Model }} & \multicolumn{2}{|c|}{$\begin{array}{c}\text { Unstandardized } \\
\text { Coefficient }\end{array}$} & \multirow{2}{*}{$\begin{array}{c}\begin{array}{c}\text { Standardized } \\
\text { Coefficient }\end{array} \\
\text { Beta } \\
\end{array}$} & \multirow[t]{2}{*}{$\mathbf{t}$} & \multirow[t]{2}{*}{ Sig. } \\
\hline & & B & Std. Error & & & \\
\hline \multirow[t]{4}{*}{1} & (Constant) & 1,374 & 0,942 & & 1,459 & 0,148 \\
\hline & Kualitas Produk & 0,238 & 0,095 & 0,246 & 2,501 & 0,014 \\
\hline & Persepsi Harga & 0,285 & 0,102 & 0,272 & 2,801 & 0,006 \\
\hline & Citra Merek & 0,361 & 0,108 & 0,337 & 3,331 & 0,001 \\
\hline
\end{tabular}

Sumber: Data diolah, 2017

Tabel 8. Hasil Analisis Jalur Persamaan Regresi 2

\begin{tabular}{llccccc}
\hline \multirow{2}{*}{ Model } & \multicolumn{2}{c}{ Unstandardized Coefficient } & \multirow{2}{*}{$\begin{array}{c}\text { Standardized } \\
\text { Coefficient }\end{array}$} & \multirow{2}{*}{ t } & Sig. \\
\cline { 3 - 5 } & & B & Std. Error & Beta & & \\
\hline $1 \quad$ & (Constant) & 1,374 & 0,942 & & 1,459 & 0,148 \\
& Kualitas Produk & 0,238 & 0,095 & 0,246 & 2,501 & 0,014 \\
& Persepsi Harga & 0,285 & 0,102 & 0,272 & 2,801 & 0,006 \\
& Citra Merek & 0,361 & 0,108 & 0,337 & 3,331 & 0,001 \\
\hline
\end{tabular}

Sumber: Data diolah, 2017

Setelah menghitung nilai dari $\beta$ koefisien selanjutnya diketahui nilai error pada masing masing persamaan regresi adalah $\varepsilon_{1}=0,641$ dan $\varepsilon_{2}$ $=0,749$. Nilai dari determinasi total $\left(\mathrm{R}^{2} \mathrm{~m}\right)$ adalah 0,769 . Hasil ini menggambarkan 76,9 persen variasi variabel loyalitas pelanggan dijelaskan oleh kepuasan pelanggan, kualitas produk, persepsi harga dan citra merek, sedangkan sebesar 23,1 persen dijelaskan oleh faktor lain yang tidak dimasukkan kedalam model.

Data pada Tabel 7. diketahui nilai dari $\beta_{1}=0,246$ dengan $\rho$ value $=0,014$. Nilai $\beta>0$ dan nilai $\rho$ value $\leq 0,05$, sehingga $\mathbf{H}_{1}$ diterima. Kualitas produk berpengaruh positif dan signifikan terhadap kepuasan pelanggan. Semakin tinggi kualitas produk smartphone merek Oppo, maka kepuasan pelanggan juga akan semakin tinggi. Hasil rangkuman penilaian responden yang disajikan dalam Tabel 7. menunjukkan bahwa penilaian responden terhadap kualitas produk berada dalam kategori sangat baik sehingga menghasilkan tingkat kepuasan berada dalam kategori sangat baik. Responden merasa puas dengan keistimewaan yang dimiliki produk berupa keunggulan kamera yang miliki produk smartphone merek Oppo. Strategi Oppo dalam menjadikan kualitas kamera sebagai keunggulan kompetitifnya berhasil meningkatkan kepuasan pelanggan terhadap produknya. Hasil penelitian ini mendukung temuan sejumlah penelitian terhadahulu seperti Mulyono dkk. (2007), Hermawan (2011), Putri dkk. (2013), Wedarini (2013) dan Bailia dkk. (2014) yang menunjukan bahwa kualitas produk berpengaruh positif signifikan terhadap kepuasan pelanggan.

Data pada Tabel 7. diketahui nilai dari $\beta_{2}=0,272$ dengan $\rho$ value $=0,006$. Nilai $\beta>0$ dan nilai $\rho$ value $\leq 0,05$, sehingga $\mathbf{H}_{2}$ diterima. Persepsi harga berpengaruh secara positif dan signifikan terhadap kepuasan pelanggan. Semakin baik persepsi harga konsumen terhadap produk smartphone merek Oppo, maka akan semakin tinggi kepuasan pelanggan. Hasil rangkuman penilaian responden yang disajikan dalam Tabel 7. Menunjukkan bahwa penilaian responden terhadap persepsi harga berada dalam kategori sangat baik sehingga menghasilkan tingkat kepuasan berada dalam kategori sangat baik. Responden merasa puas dengan daya saing harga dan kesesuaian manfaat yang diberikan produk smartphone merek Oppo. Strategi Oppo dengan fokus menyasar konsumen segmen menengah menjadikan Oppo menawarkan produk dengan harga yang lebih terjangkau. Menawarkan harga produk yang bersaing dengan tetap menjaga kualitas mampu meningkatkan kepuasan pelanggan. Konsumen merasa puas terhadap kesesuaian manfaat yang dirasakan dengan harga yang dibayarkan saat menggunakan smartphone merek Oppo. Hasil penelitian ini mendukung temuan sejumlah penelitian terhadaulu seperti Yoganthara (2013), Montung dkk. (2015), Liman (2016), Darmawan dan Ekawati (2017) dan Sulastri (2017) yang menunjukkan bahwa persepsi harga memiliki pengaruh positif dan signifikan terhadap kepuasan pelanggan. 
Data pada Tabel 7. diketahui nilai dari $\beta_{3}=0,337$ dengan $\rho$ value $=0,001$. Nilai $\beta>0$ dan nilai $\rho$ value $\leq 0,05$, sehingga $\mathbf{H}_{3}$ diterima. Citra merek memiliki pengaruh positif dan signfikan terhadap kepuasan pelanggan. Semakin tinggi citra merek produk smartphone merek Oppo, maka akan semakin tinggi pula kepuasan pelanggan hasil rangkuman penilaian responden yang disajikan dalam Tabel 7. menunjukkan bahwa penilaian responden terhadap citra merek berada dalam kategori baik sehingga menghasilkan tingkat kepuasan berada dalam kategori sangat baik. Responden merasa puas dengan kompetensi yang dimiliki smartphone merek Oppo. Strategi Oppo dalam menjaga kualitas meskipun menawarkan harga yang terjangkau mampu meningkatkan nilai dari citra mereknya. Oppo mampu membangun citra merek yang baik dibenak konsumen ditengah persepsi produk produk asal China yang memiliki citra yang buruk. Oppo membuktikan bahwa meskipun menawarkan harga yang terajangkau, produk mereka mampu bersaing dengan smartphone merek lain. Kompetensi produk yang tergambar pada citra merek Oppo mampu meningkatkan kepuasan pelanggan.Hasil penelitian ini mendukung temuan sejumlah penelitian terhadahulu sepertiSaputra (2013), Harianto dan Subagio (2013), Kurniawati dkk (2014), Pusparani dan Rastini (2014), serta Susanti dan Wardana (2015) menujukan bahwa citra merek berpengaruh positif dan signifikan terhadap kepuasan pelanggan.

Data pada Tabel 8. diketahui nilai dari $\beta_{4}=0,662$ dengan $\rho$ value $=0,000$. Nilai $\beta>0$ dan nilai $\rho$ value $\leq 0,05$, sehingga $\mathbf{H}_{\mathbf{4}}$ diterima. Kepuasan pelanggan berpengaruh positif dan signifikan terhadap loyalitas pelanggan. Semakin tinggi kepuasan pelanggan terhadap produk smartphone merek Oppo, maka akan semakin tinggi pula loyalitas pelanggan terhadap produk tersebut. Hasil rangkuman penilaian responden yang disajikan dalam Tabel 8 . menunjukkan bahwa kepuasan pelanggan berada dalam kategori sangat baik sehingga menghasilkan tingkat loyalitas pelanggan berada dalam kategori sangat baik. Responden menjadi pelanggan yang loyal karena merasa puas dengan produk smartphone merek Oppo. Kualitas produk, persepsi harga, dan citra merek smartphone merek Oppo mampu meningkatkan kepuasan pelanggan. Kepuasan ini berdampak secara positif dan signifikan terhadap loyalitas pelanggan produk smartphone merek Oppo. Strategi Oppo dalam meningkatkan kepuasan pelanggannya dengan menghadirkan kualitas produk yang baik, persepsi harga yang baik dan citra yang kuat mampu menciptakan loyalitas pelanggan. Pelanggan yang loyal ini akan merekomendasikan produk smartphone merek Oppo yang digunakannya kepada orang lain. Rekomendasi ini akan membantu perusahaan dalam mendatangkan konsumen baru. Hasil penelitian ini mendukung temuan sejumlah penelitian terhadahulu seperti Jayaputra (2009), Ishak dan Luthfi (2011), Kurniasari dan Ernawati (2012), Rachmawati (2014) serta Margaretha dan Sunaryo (2014) yang menunjukan kepuasan pelanggan berpengaruh positif dan signifikan terhadap loyalitas pelanggan.

Hasil pada analisis jalur pada Tabel 8. dapat diketahui variabel citra merek merupakan variabel yang paling berpengaruh terhadap kepuasan pelanggan. Citra produk smartphone merek Oppo sebagai produk smartphone yang berkompeten memiliki pengaruh paling besar dalam meningkatkan kepuasan pelanggan. Diposisi kedua, variabel persepsi harga merupakan variabel yang dapat mempengaruhi kepuasan pelanggan, kesesuaian manfaat yang dirasakan dengan harga yang dibayarkan, berpengaruh terhadap kepuasan pelanggan. Diposisi terakhir, adalah variabel kualitas produk yang berpengaruh terhadap kepuasan pelanggan. Keistimewaan berupa kualitas kamera yang baik, mampu menciptakan kepuasan pelanggan. Ketiga variabel ini dapat menciptakan kepuasan pelanggan pada produk smartphone merek Oppo, dampak lebih jauhnya kepuasan ini telah menciptakan loyalitas pelanggan. Pelanggan yang loyal, akan merekomendasikan produk smartphone merek Oppo kepada orang lain.

\section{SIMPULAN DAN SARAN}

Berdasarkan hasil pembahasan, dapat disimpulkan bahwa kualitas produk berpengaruh positif dan signifikan terhadap kepuasan pelanggan. Persepsi harga berpengaruh positif dan signifikan terhadap kepuasan pelanggan. Citra merek berpengaruh positif dan signifikan terhaap kepuasan pelanggan. Kepuasan berpengaruh positif dan signifikan terhadap loyalitas pelanggan. Citra merek yang dimiliki produk smartphone merek Oppo merupakan variabel yang paling mempengaruhi tingkat kepuasan pelanggan.

Hasil penelitian ini menunjukkan bahwa kualitas produk, persepsi harga dan citra merek berpengaruh positif dan signifikan terhadap kepuasan pelanggan. Citra merek merupakan variabel yang paling mempengaruhi kepuasan pelanggan. Membentuk citra merek yang positif dibenak konsumen, dapat 
menjadi strategi bagi perusahaan untuk menyasar segmen pasar yang baru. Perusahaan dapat menciptakan loyalitas pelanggan terhadap produknya melalui peningkatan kepuasan pelanggan.

\section{REFERENSI}

Alma, Buchari. 2005. Manajemen Pemasaran dan Pemasaran Jasa. Bandung : Alfabetta.

- - Anonymous.2013.Tentangppo. http:// www.Oppo.com/id/about-us/. Diakses pada 8 Juli 2017.

Anonymous.2017.Top Brand Kategori Telekomunikasi/IT Fase 1. http://www.top brand-award.com/top-brand-survey/surveyresult/top_brand_index_2017_fase_1. Diakses pada 8 Juli 2017.

Asadi, Ali, Javad Khazaei Pool, dan Mohammand Reza Jalilvand.2014. The Effect Of Perceived Price Fairness Through Satisfaction And Loyalty On International Tourists' Price Acceptance Of Islamic-Iranian Art Products. Education, Business and Society : Contemporary Middle Eastern Issues, 7(4), pp. $201-215$

Asosiasi Penyelenggara Jasa Internet Indoneisa dan Mastel. 2016. Konklusi Survey Ekosistem DNA (Device, Network, \& Apps). http://apjii.or.id. Diakses pada 8 Juli 2017.

Bailia, Jefry F.T, Agus Supandi Soegoto dan Sjendry Serulo R. Loindong. 2014. Pengaruh Kualitas Produk, Harga Dan Lokasi Terhadap Kepuasan Konsumen Pada Warung - Warung Makan Lamongan Di Kota Manado.Jurnal $E M B A, 2(3)$, hal.1768 - 1780.

Beneke, Justin dan Natalia Zimmerman. 2014. Beyond Privat Label Panache : The Effect of Store Image And Perceived Price on Brand Prestige. Journal of Consumer Marketing, 31(4), pp.301-311.

Bennett, Rebekah, 2005. The Brand Loyalty Life Cycle: Implication For Marketeers. Brand Management, 12(4), pp.250 - 263.

Brookshire, Jung Ha dan So Hyang Yoon. 2012. Country of Origin Faktors Influencing US Consumer Perceived Price for Multinational Products. Journal of Consumer Marketing, 29(6), pp. 445 - 454.

Chaeriah, Ella Siti. 2016. Pengaruh Harga, Citra Merek, Dan Kualitas Produk Terhadap Loyalitas Pengguna Smartphone Samsung (Studi Pada Mahasiswa Magister Manajemen UNKRIS). Jurnal Manajemen Bisnis Krisnadwipayana, 4(3), hal.1-9.
Consuegra, David Martin, Arturo Molina, dan Agueda Esteban. 2007. An Integrated Model of Price,Saticfaction and Loyalty : An Empirical Analysis in The Service Sector. Journal of Product and Brand Mangement, 16(7), pp. $459-468$.

Darmawan, Putu Ayu Dessy Trisnadewi, dan Ni Wayan Ekawati. 2017. Pengaruh Kepuasan Konsumen Memediasi Harga Terhadap Loyalitas Konsumen Dalam Berbelanja Pada Florist Online Di Kota Denpasar. E-Jurnal Manajemen Universitas Udayana, 6(4), hal.2076-2104.

Divett, Megan, Nadia Crittenden dan Ron Henderson. 2003. Actively Influencing Consumer Loyalty.Journal of Consumer Marketing,20(2), pp.109-126.

Duffy, Dennis L. 2003. Commentary Internal and External Fators Which Affect Customer Loyalty. Journal of Consumer Marketing, 20(5), pp. $480-485$.

Espejel, Joel, Carmina Fandos dan Carlor Flavian. Consumer Satisfaction a Key Faktor of Consumer Loyalty and Buying Intention of a PDO Food Product. British Food Journal, 110(9), pp.865-881.

Fatih, Muhammad Fardan Al, Suharyono, dan M. Kholid Mawardi. 2016. Analisis Citra Merek Berdasarkan County of Origin (Studi Tentang Citra Merek Smartphone Asal Amerika Serikat dan Adal China Pada Mahasiswa Universitas Brawijaya). Jurnal Administrasi Bisnis, 39(1),hal.42 - 50.

Ghanimata, Fifyanita. dan Mustafa Kamal. 2012. Analisis Pengaruh Harga, Kualitas Produk, dan Lokasi Terhadap Keputusan Pembelian (Studi Pada Pembelian Produk Bandeng Juwana Erlina Semarang). Diponegoro Journal of Management, 1(2), hal.1-10.

Harianto, David dan Hartono Subagio. 2013. Analisia Pengaruh Kualitas Layanan, Brand Image Dan Atmosfer Terhadap Loyalitas Dengan Kepuasan Konsumen Sebagai Variabel Intervening Konsumen Kedai Deja-Vu Surabaya. Jurnal Manajemen Pemasaran, 1(1), hal.1-8.

Hermawan, Budi. 2011. Pengaruh Kualitas Produk Terhadap Kepuasan, Reputasi Merek dan Loyalitas Konsumen Jamu Tolak Angin PT. Sido Muncul. Jurnal Manajemen Teori dan Terapan, 4(2), hal.9-17.

Iglesias, Marta Pedraja dan M. Jesus Yagile Guillen. 2004. Perceived Quaity and Price : Their Impact on the Satisfaction of Restaurant 
Customers. Internasional Journal of Contemporary Hospital Management, 16(6), pp. $373-379$.

Ishak, Asmani dan Zhafiri Luthfi. 2011. Pengaruh Kepuasan dan Kepercayaan Konsumen Terhadap Loyalitas : Studi Tentang Peran Mediasi Switching Cost. Journal Siasat Bisnis, 15(1), hal. 55-66.

Jayaputra, Arnold.2009. Pengaruh Kepuasan Kepercayaan dan Komitmen Terhadap Loyalitas Konsumen Telekomunikasi. Business and Management Journal Bunda Mulia, 5(1),hal.65-92.

Kotler, Philip and Kevin Lane Keller.2009. Manajemen Pemasaran Edisi Ketiga Belas Jilid 1.Jakarta : Erlangga.

Kotler, Philip dan Gary Amstrong.2010. PrinsipPrinsip Pemasaran. Jakarta : Erlangga.

Koubaa, Yamen. 2008. Country Of Origin, Brand Image Perception, and Brand Image Structure. Asia Pacific Journal of Marketing and Logistics, 20(2), pp. 139 - 155.

Kurniasari, Nina dan Nina Ernawati. 2012. Pengaruh Kepuasan Pelanggan, Kepercayaan dan Harga Terhadap Loyalitas Pelanggan Laundry Kencling Semarang. Jurnal Mahasiswa $Q$ Man, 1(3), hal.57-68.

Kurniawati, Dewi, Suharyono dan Andriani Kusumawati. 2014. Pengaruh Citra Merek dan Kualitas Produk Terhadap Kepuasan dan Loyalitas Pelanggan (Studi Pada Pelanggan KFC Cabang Kawi Malang). Jurnal Administrasi Bisnis (JAB), 14(2), hal. 1-9

Liman, Piter. 2016. Analisis Pengaruh Kualitas Produk, Kualitas Layanan dan Persepsi Harga Terhadap Kepuasan Pelanggan pada Minyak Goreng Kemasan CV. Indo Sari Abadi. Jurnal Komunikasi Bisnis dan Manajemen, 3(6), hal.95-107

Luthfi, Ahmad. 2014. Di Indonesia Smartphone Sudah Menjadi Kebutuhan Utama.http:// techno.okezone.com/read/2014/05/13/57/ 984293/di-indonesia-smartphone-sudahmenjadi-kebutuhan-utama. Diakses pada 8 Juli 2017.

Margaretha, Dona dan Sunaryo. 2014. Pengaruh Kualitas Produk dan Saluran Distribusi Terhadap Loyalitas Merek Melalui Kepuasan Pelaggan (Studi Kasus Konsumen Penikmat Rokok Tambang Emas Alami Dan Coklat Alami). Jurnal Ilmiah Mahasiswa FEB Universitas Brawijaya, 3(2), hal. 54 - 69.
Marketeers Editor. 2013. Oppo Siap Jajal Segmen Kelas Menengah Indonesia. http://marketeers. com/Oppo-siap-jajal-segmen-kelasmenengah-indonesia/. Diakses pada 8 Juli 2017.

Montung, Pamela, Jantje Sepang dan Decky Adare. 2015. Pengaruh Kualitas Produk, Kualitas Layanan dan Persepsi Harga Terhadap Kepuasan Pelanggan Di Restoran Kawan Baru. Jurnal Berkala Ilmiah Efisiensi, 15(5), hal.678-689.

Moraga, Eduardo Torres, Arturo Z. Vasques Parraga dan Jorge Zamora Gonzales. 2008. Customer Satisfaction and Loyalty: Start With The Product, Culmite With The Brand. Journal of Consumer Marketing, 25(5), pp.302 - 313.

Mulyono, Bayu Hadyanto, Yoestini, Rini Nugraheni dan Mustofa Kamal. 2007. Analisis Pengaruh Kualitas Produk Dan Kualitas Layanan Terhadap Kepuasan Konsumen (Studi Kasus Pada Perumahan Puri Mediterania Semarang). Jurnal Studi Manajemen dan Organisasi Universitas Diponogoro, 4(2), hal.91 - 100.

Nugraheni, Rini dan Comaeni Enril Ferdinan. 2013. Analisis Pengaruh Persepsi Harga, Persepsi Kualitas Produk dan Promosi Terhadap Keputusan Pembelian Sepeda Motor Suzuki (Studi pada Pembeli - Penguna Sepeda Motor Suzuki di Kota Solo). Diponegoro Journal of Management, 2(2), hal. 1-8.

Nurlinda, R.A.2013. Pengaruh Customer Satisfaction Strategy Terhadap Peningkatan Kepuasan Konsumen. 2013. Forum Ilmiah, 10(2), hal. $172-181$.

Peter, J. Paul and Jerry C. Olson. 2000. Consumer Behavior : Perilaku Konsumen dan Strategi Pemasaran Jilid 1 Edisi Keempat. Jakarta : Erlangga.

Pusparani, Putu Ayu Yulia dan Ni Made Rastini. 2014. Pengaruh Kualitas Produk Dan Brand Image Terhadap Kepuasan Konsumen dan Loyalitas Pelanggan Kamera Canon Digital Single Lens Reflex (DSLR) Di Kota Denpasar. E-Jurnal Manajemen Universitas Udayana, 3(5), hal.1311 - 1319.

Putri, Adhis Anggiany. 2017. Demi Trend "Selfie" Tetap Eksis. http://tekno. kompas.com/read/ 2017/02/08/1017007/demi.tren.selfie. tetap.eksis. Diakses pada 8 Juli 2017.

Putri, Desa Irana, Wahyu Hidayat dan Reni Shinta Dewi.2013. Pengaruh Kualitas Produk Dan Lokasi Terhadap Loyalitas Pelanggan Memalui 
Kepuasan Pelanggan Sebagai Variabel Intervening. Jurnal Administrasi Bisnis, 2(2), hal.1-9.

Rachmawati, Rina. 2014. Pengaruh Kepuasan Terhadap Loyalitas Pelanggan (Sebuah Kajian Terhadap Bisnis Makanan). Teknobuga, 1(1), hal.66-79.

Riduwan dan Engkos Ahman Kuncoro. 2008. Cara Menggunakan dan Memaknai Analisis Jalur (Path Analysis).Bandung : Alfabeta.

Saputra, Falla Ilhami. 2013. Kualitas Layanan, Citra Dan Pengaruhnya Terhadap Loyalitas Melalui Kepuasan Pelanggan (Studi Pada PT. Bank BNI 46 Sentra Kredit Kecil Surabaya).Jurnal Aplikasi Manajemen Universitas Brawijaya, 11(3), hal.445- 457.

Saraswati, Agung Ratih dan Ketut Rahyuda. 2017. Brand Image Memediasi Kualitas Produk Dan Harga Dengan Keputusan Pembelian Smartphone Apple Di Kota Denpasar. EJurnal Manajemen Universitas Udayana, 6(6), hal.3252-3282.

Sembiring, Inka Janira, Suharyono dan Andriani Kusumawati. Pengaruh Kualitas Produk Dan Kualitas Pelayanan Terhadap Kepuasan Pelanggan Dalam Membentuk Loyalitas Pelanggan (Studi Pada Pelanggan Mcdonald's MT. Haryono Malang). Jurnal Administrasi Bisnis Universitas Brawijaya, 15(1), hal.1-10.

Seno, Diana dan Lukas Bryan A. 2007. The Equity of Product Endorsement by Celebrities a Conceptual Framework From a Co Branding Perspective. European Journal of Marketing, 41(1/2),pp.121 - 134.

Shimp, Terence A. 2014. Komunikasi Pemasaran Terpadu dalam Periklanan dan Promori Edisi 8. Jakarta : Salemba Empat.

Silva, Tarsis Souza dan Janaina de Moura Engracia Giraldi. 2010. The influence of store image on customer saticfaction : a case study of a shoe strore. Brazilian Bussines Review, 7(2), pp. 60-77

Sinaga, Krisman dan Rini Novianti. 2016. Analisis Pengaruh Citra Merek, Kualitas Produk dan Persepsi Harga Terhadap Loyalitas Konsumen Produk Pasta Gigi Pepsodent. Global, 1(10), hal. $1-11$.

Sondoh, Stephen L., Maznah Wan Omar, Nabsiah Abdul Wahid, Ishak Ismail dan Amran Harun. 2007. The Effect of Brand Image on Overall Satisfaction and Loyalty Intention In The
Context of Color Cosmetic. Asian Academy of Management Journal, 12(1), pp. 83-107. Sugianto,Danang. 2017. HP di Kisaran Harga Ini Paling Banyak Dibeli Konsumen. https://finance. detik.com/berita-ekonomi-bisnis/3536749/ hp-di-kisaran-harga-ini-paling-banyakdibeli-konsumen. Diakses pada 8 Juli 2017

Sulastri, Tuti. 2017. Pengaruh Kualitas Pelayanan dan Persepsi Harga Terhadap Kepuasan Mahasiswa Serta Implikasinya Pada Citra Perguruan Tinggi. Jurnal Inspirasi Bisnis dan Manajemen, 1(1), hal.41-52.

Sulistiyanto, F.X dan Euis Soliha.2016.Pengaruh Persepsi Harga, Citra Perusahaan dan Citra Merek Terhadap Kepuasan dan Loyalitas Pelanggan Pada Apotek "Dela" Semarang. Simposium Prosiding Seminar Nasional and Call For Paper Kinerja Perbankan, Bisnis Dan Ekonomi Indonesia Menghadapi ASEAN Economic Community 2015, 25-30 Oktober 2016. Susanti, Ni Putu Hani dan I Made Wardana. 2015. Pengaruh Kualitas Produk dan Citra Merek Terhadap Kepuasan dan Loyalitas Pelanggan Pada Produk Kosmetik Hijau Merek The Body Shop. E-Jurnal Manejemen Universitas Udayana, 4(5), hal.622 - 636.

Taufandra, Muhammad dan I Gede Bayu Rahanatha. 2014. Pengaruh Citra Merek Terhadap Persepsi Kualitas dan Loyalitas Merek. E-Jurnal Manajemen Universitas Udayana, 3 (11), hal. $3342-3357$.

Wardani, Agustin Setyo. 2016. Apa Saja Pencapaian Oppo Selama 3 Tahun di Indonesia?. http:// tekno.liputan6.com/read/2661370/apasaja-pencapaian-Oppo-selama-3-tahun-diindonesia. Diakses pada 30 Agustus 2017.

Wedarini, Ni Made Sinta. 2013. Pengaruh Kualitas Produk Terhadap Kepuasan dan Loyalitas Pelanggan Telkom Flexi. E-Jurnal Manajemen Universitas Udayana, 2(5), hal.495 - 512.

Wirawan, Nata. 2002. Cara Mudah Memahami Statistik 1 (Statistik Deskripstif) Edisi 1. Denpasar : Keramat Emas

Yoganthara, Agasi Aji. Pengaruh Persepsi Harga Dan Kualitas Pelayanan Terhadap Loyalitas Melalui Kepuasan Konsumen (Studi Empiris Pada Radja Futsal Stadius Cabang Majapahit Semarang). Jurnal Dimanika Manajemen, 2(5), hal.113-128.

Yu, Yi Ting dan Alison Dean. 2000. The Contribution of Emotional Satisfaction To Consumer Loyalty. International Journal of Service Industry Management, 12(3),pp. 234 - 250. 